\title{
Evaluation of preventive homeopathic treatment against Colibacillosis in swine production
}

\author{
Cidéli de Paula Coelho',2, Francisco Rafael Martins Soto², \\ Erlete Rosalina Vuaden ${ }^{3}$, Priscilla Anne Melville ${ }^{2}$, \\ Flávia Carolina Souza Oliveira², Nilson Roberti Benites ${ }^{2}$
}

(1) FACIS - IBEHE, São Paulo, Brazil; (2) USP - Universidade de São Paulo, São Paulo, Brazil; (3) M. Cassab - Nutrição Animal, São Paulo, Brazil;

\begin{abstract}
Escherichia coli is the most important etiologic agent implied in neonatal diarrhea in swine; colibacillosis is the disease with highest impact in production of swine. The demands of consumers for meat without chemical residues and the ban on the use of antibiotics and chemotherapics in production of swine compelled to find alternative therapeutic and preventive treatments. Aims: to assess homeopathic treatment as preventive against colibacillosis in swine. Methods: the study was conducted in a farm in Mato Grosso, Brazil; stools of 4 piglets with diarrhea were collected to establish the presence of $E$. coli; concomitantly it was performed a clinical exam to identify the symptoms leading to the choice of a homeopathy remedy. Newborn piglets were divided into 4 groups $(\mathrm{n}=11$ or 12$)$ : 1 ) control, subjected to antibiotic treatment against diarrhea; 2) homeopathic treatment, performed with Phosphorus $30 \mathrm{cH}$ according to the symptoms collected; 3) biotherapic treatment, performed with Escherichia coli 30cH prepared from the locally obtained bacteria; 4) homeopathic + biotherapics treatment. Results: all 3 groups treated with homeopathy/isotherapy presented a significant reduction of diarrhea compared to the control group $(\mathrm{p}=0.02)$; the group treated with Phosphorus $30 \mathrm{cH}+$ Escherichia coli $30 \mathrm{cH}$ presented the highest weight gain which was significant by comparison to all other groups $(p=0.001)$. Conclusion: homeopathic and biotherapics treatment were more effective than antibiotics in the control of diarrhea in newborn piglets; combination of homeopathic and isopathic treatment resulted in the highest weight gain. These results suggest that homeopathy and isopathy are effective alternatives for the treatment of diarrhea by $E$. coli in newborn swine.
\end{abstract}

Keywords: Escherichia coli; Diarrhea; Swine; Homeopathy; Isopathy; Effectiveness.

\section{Introduction}

Diarrhea became a disease with significant economic impact in the production of swine due to the systems of intensive farming adopted [1]. Enteritis can appear in three different stages: neonatal diarrhea, appearing during the first days of life; piglet diarrhea, when it appears from the first week of life to weaning; and diarrhea after weaning. Generally, 50-60\% of deaths during the suckling stage happen during the first week of life mainly due to crushing by the sow or neonatal diarrhea. Escherichia coli is the most significant etiologic agent involved in neonatal and after weaning diarrhea in swine [2-4]; Colibacillosis is the disease with highest impact on the production of swine [5].

E. coli is a Gram-negative bacteria belonging to family Enterobacteriaceae; for a long time it was considered a commensal inhabitant of the intestinal microbiota of different animal species without significant pathogenic 
potential. This view changed gradually when several enteric and extra-intestinal diseases caused by specific serotypes of E. coli possessing several characteristic virulence factors were identified. In animals, E. coli has been associated with diarrhea, cystitis, mastitis, septicemia, nephritis, etc. Factors predisposing animals to clinical disease include age, immunological state, type of diet and exposure to pathogenic lineages [6]. Clinically, piglets may reject feeding and present watery diarrhea leading fast to dehydration, weakness and death [6].

Consumers' demands for meat without chemical residues and the ban on the use of antibiotics and chemotherapics in the production of swine, especially by European countries [7] led to seek for alternative therapeutic and preventive treatments [8]. Homeopathy in swine can be used as healing treatment but through the stimulation of the organism, it can also decrease the level of stress of populations and stimulate the reactivity of animals against bacterial, viral and endo- and ectoparasitic infections [8, 9].

Isotherapy, on the other hand, employs as prime matter for the preparation of remedies products of disease which are then subjected to homeopathic pharmacotechnics. Traditionally known as "nosodes", these preparations are currently called biotherapics and the can have a prophylactic effect on both endemic and epidemic diseases [10].

The aims of the present study were to assess the efficacy of a prophylactic treatment against colibacillosis in swine using a homeopathic remedy and biotherapics of E. coli, isolated and combined, through comparison to the standard antimicrobial treatment, as well as assess potential differences in weight gain in order to establish whether there is significant advantage in the use of less toxic medicines.

\section{Materials and methods}

The study was carried out in a swine farm in Mato Grosso, Brazil. Stools from 4 piglets with diarrhea were collected to establish the presence of E. coli. Clinical data were also collected to guide the choice of the homeopathic remedy (table 1) through repertory analysis and cross-checking in the homeopathic materia medica [11-14].

Table 1 - Repertory analysis [12]:

\begin{tabular}{|l|c|c|c|c|c|c|c|c|c|}
\hline Symptoms & Phos & Ars & Olnd & Nat-s & Dulc & Ip & Apis & Bor & Mag-c \\
\hline $\begin{array}{l}\text { Rectum, diarrhea, in } \\
\text { children (611/II) }\end{array}$ & 02 & 02 & 01 & -- & 02 & 03 & 01 & 02 & 02 \\
\hline $\begin{array}{l}\text { Stool, watery,yellow } \\
\text { (643/II) }\end{array}$ & 01 & 01 & 03 & 02 & 03 & 01 & 02 & 01 & -- \\
\hline $\begin{array}{l}\text { Stool, thin, liquid, brown } \\
\text { (642/II) }\end{array}$ & 02 & 02 & -- & 02 & -- & -- & -- & -- & 01 \\
\hline Stool, soft (641/II) & 03 & 02 & 02 & 02 & 01 & 01 & 02 & 01 & 01 \\
\hline $\begin{array}{l}\text { Generalities, weakness, } \\
\text { diarrhea from (1416/II) }\end{array}$ & 03 & 03 & 03 & 03 & 02 & 02 & 02 & 02 & 01 \\
\hline Total & $11 / 5$ & $10 / 5$ & $09 / 4$ & $09 / 4$ & $08 / 4$ & $07 / 4$ & $07 / 4$ & $06 / 4$ & $05 / 4$ \\
\hline
\end{tabular}

The study population was composed by 46 newborn piglets, which were divided into 4 groups, each one with its respective primipar mother; group were uniform regarding feeding and confinement; births and treatments were simultaneous and animals did not get in contact one with the others. 
Group 1 (control), was treated with the standard antibiotic employed at the farm, Shotapen ${ }^{\circledR}$ (procaine penicillin; benzatin penicillin; dihydrostreptomycin) $1 \mathrm{ml}$ single dose intramuscular. Group 2 was treated with Phosphorus 30cH, Group 3 was treated with E. coli $30 \mathrm{cH}$ prepared according to homeopathic pharmacotechnics [15, 16] from E. coli isolated from the sick animals; Group 4 was treated with a combination of Phosphorus $30 \mathrm{cH}$ and E. coli $30 \mathrm{cH}$ in the same scheme. The homeopathic and isopathic remedies were prepared in hydro-alcoholic vehicle $30 \%$ and prescribed 2 drops p.o. once a day to each piglet for 12 consecutive days, when stools were collected to seek for E. coli. Distribution into groups was randomized double-blind.

Statistical analysis was performed by Fischer's Test with software GRAPHPAD INSTAT 1992-98.

\section{Results}

Regarding the number of animals with diarrhea at the end of treatment, there was a positive significant difference for the 3 groups treated with homeopathy and/or isopathy by comparison to the control group $(\mathrm{p}=0.02)$ (table 2). There was no significant difference between the 3 groups that took homeopathic and/or isopathic treatment. There were 2 deaths in the control group.

Table 2 - Number of animals with diarrhea at the beginning and the end of treatment.

\begin{tabular}{|l|c|c|}
\hline Group & $\begin{array}{l}\text { Beginning (number of } \\
\text { sick animals/total } \\
\text { number of animals) }\end{array}$ & $\begin{array}{l}\text { End (number of sick } \\
\text { animals/total number of } \\
\text { animals) }\end{array}$ \\
\hline Control & $6 / 11$ & $4 / 09^{* *}$ \\
\hline Phos $30 \mathbf{c H}$ & $11 / 12$ & $0 / 12$ \\
\hline E. coli $\mathbf{3 0 c H}$ & $5 / 12$ & $0 / 12$ \\
\hline Phos $30 \mathbf{c H}+$ E. coli $\mathbf{3 0 c H}$ & $9 / 11$ & $0 / 11$ \\
\hline
\end{tabular}

*Fischer's test $\mathrm{p}=0.02$ regarding the other 3 groups; $\bullet 2$ animals died

Table 3 - Weight average at the beginning of treatment and weaning in $\mathrm{kg}$.

\begin{tabular}{|l|c|c|c|}
\hline Group & $\begin{array}{c}\text { Beginning (average } \\
\text { weight/number of animals) }\end{array}$ & $\begin{array}{c}\text { Weaning (average } \\
\text { weight/number of animals) }\end{array}$ & $\begin{array}{c}\text { Average weight } \\
\text { gain (kg) }\end{array}$ \\
\hline Control & $1.618 / 11$ & $5.444 / 09^{\dagger}$ & 3.826 \\
\hline Phos $\mathbf{3 0 c H}$ & $1.917 / 12$ & $6.090 / 12$ & 4.173 \\
\hline E. coli $\mathbf{3 0 c H}$ & $1.717 / 12$ & $6.455 / 11^{\bullet}$ & $4.738^{*}$ \\
\hline $\begin{array}{l}\text { Phos } \mathbf{3 0 c H}+ \\
\text { E. coli } \mathbf{3 0 c H}\end{array}$ & $1.200 / 11$ & $6.090 / 11$ & $4.890^{* *}$ \\
\hline
\end{tabular}

$\nmid 2$ animals died; $\bullet 1$ animal died after the end of the study but before weaning; *Fischer’s Test $\mathrm{p}=0.001$ regarding $P$ hos $30 \mathrm{cH}$ and $\mathrm{p}=0.05$ regarding control group;

** Fischer's Test $\mathrm{p}=0.001$ regarding all 3 other groups. 
Group 4 (Phos $30 \mathrm{cH}+$ E. coli $30 \mathrm{cH})$ showed the highest weight gain, significant by comparison to the other 3 groups $(\mathrm{p}=0.001)$, followed by Group $3(E$. coli $30 \mathrm{cH})$, again significant by comparison to Group 2 (Phos $30 \mathrm{cH})$ $(\mathrm{p}=0.001)$ and Group 1 (control) $(\mathrm{p}=0.05)$. Weight gain was higher, but not significant, in Group 2 (Phos 30cH) than in Group 2 (control) (Table 3; Figure 1).

Figure 1 - Weight gain (in kg).

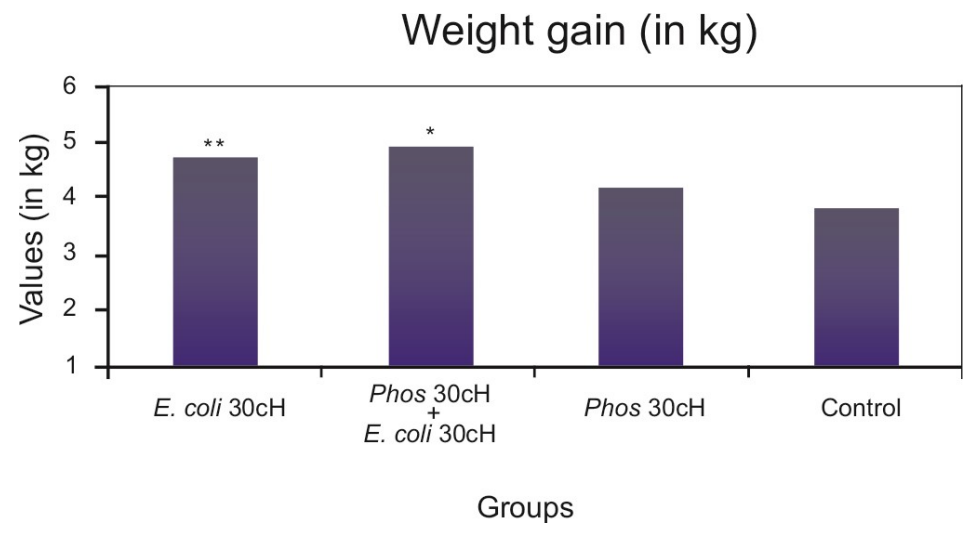

\section{Discussion}

Albrecht and Schütte [17] compared the use of antibiotics/chemotherapics and homeopathic treatment in intensive system of swine farming in animals in stage of fattening. In this study, it was compared chemotherapics (chlortetracycline. sulfamethazine and dimetridazole) in prophylactic and therapeutic doses and homeopathic remedies Cuprum metallicum 4x, Drosera rotundifolia 1x, Ipecacuanha 3x, Ferrum phosphoricum 4x and Nux vomica $4 \mathrm{x}$ as well as placebo, supplied in the drinking water. Variables assessed were general incidence of disease and incidence of respiratory illnesses; results were better for the group treated with homeopathy, supporting the outcomes of our present study.

There are other references in the literature pointing to the efficiency of biotherapics, such as Berchieri et al. [18] which showed that biotherapics prepared from Salmonella enterica serovar enteritidis supplied in drinking water to 180 chickens were efficient in decreasing culture growth of bacteria collected from cloacal swabs.

A study by Soto et al. [19] sought to assess the use of biotherapic of Erysipelothrix rhusiopathiae and homeopathic medicine (Belladona $6 \mathrm{cH}$ and Rhus toxicodendron $6 \mathrm{cH}$ in complex) continually mixed in reproductive rations in the prevention of swine erysipela by comparison to the use of antibiotics (oxytetracyclin) also mixed to ration and vaccination with bacterin in a commercial swine farm. There was significant $57 \%$ reduction of female mortality $(\mathrm{p}=0.04)$; homeopathic medicine + biotherapics resulted in a significant reduction $(p=0.01)$ of natimortality and of the number of abortions in reproductive females by comparison to standard conventional prophylaxis.

The study by Fontes et al. [20] compared homeopathic remedy Cantharis vesicatoria $6 \mathrm{cH}$ and 30cH, biotherapics Urina 30cH, E. coli $30 \mathrm{cH}$ and Colibacillinum $30 \mathrm{cH}$ and conventional antibiotic (nalidixic acid) prescribed both therapeutically and prophylactically p.o. to Wistar rats experimentally contaminated by urethral catheter with E. coli. After induction of urinary infection, Cantharis vesicatoria $6 \mathrm{cH}$ and $30 \mathrm{cH}$ and nalidixic acid were effective in the treatment of the infected animals; conversely, when a 5 -day treatment preceded induction of urinary infection, Urina $30 \mathrm{cH}$ showed the best results.

A pilot study was carried out to assess the effects of biotherapic of Boophilus microplus in cattle naturally infested; 27 animals were divided into 3 groups: 1) control, without any treatment; 2) conventional amitraz; and 3) biotherapic $12 \mathrm{cH}$. The latter group exhibited a significant reduction in the number of ticks by comparison to the control group $(\mathrm{p}<0.05)$, whereas there was no significant difference between the groups treated with amitraz and biotherapics $(\mathrm{p}<0.05)$. These results suggest that the biotherapics can be efficient in 
the control of B. microplus in cattle [21]. This, as well as the studies mentioned above show good results for biotherapics both single and combined with homeopathic medicines.

The productive chain of swine has an important role in the economic and social development of several Brazilian states, either traditionally or more recently [22]. As more than $70 \%$ of meat is processed, this activity results in generation of jobs and income in the rural environment, with a reflection in other economic sectors and the urban environment [23].

Homeopathic treatment is advantageous by comparison to standard approaches as it allows to bypass negative effects such as induction of bacterial resistance and presence of chemical residues in the meat, which is a particularly critical feature in technified swine production. It must be taken into account the growing demand to decrease or abolish the use of antibiotics in production animals (swine, cattle and poultry), both p.o. and parenteral, according to the standards of meat-importing countries, particularly the European Union $[17,24]$.

According to Soto et al. [8, 25] homeopathic treatment allowed a larger number of animals to enter in the final fattening stage, resulting in an increase of the number of animals produced by sow/year, as well as in a reduction of the mortality rate in the nursing and fattening stage. Moreover, annual costs were lower by comparison to the use of conventional treatment, increasing thus the performance of swine production, with higher incomes for producers.

\section{Conclusion}

Homeopathic and isopathic treatment were more effective than treatment with antibiotics in the control of diarrhea in piglets; weight gain was higher in the groups treated with homeopathic remedy-biotherapic association and biotherapic alone. These results suggest that homeopathic and isopathic treatment can be a suitable and safe alternative to the use of antibiotics, while avoiding environmental damage.

\section{Acknowledgments:}

To Dr Márcia A. Gutierrez, from Farmácia Sensitiva, who supplied the remedies and Andréia Tirloni, owner of the farm were the study was carried out.

\section{References}

[1] Zlotowski P, Driemeier D, Barcellos DESN. Patogenia das diarréias dos suínos: modelos e exemplos. Acta scientiae veterinariae. 2008; 36(1): s81-s86. [portuguese].

[2] Fairbrother JF. Escherichia coli diarrhea. In: Straw BE, D'Allaire S, Mengeling WL, Taylor DJ, editors. Diseases of swine. $8^{\text {th }}$ ed. Oxford: Blackwell science Ltd; 1999. p. 433-440.

[3] Calderario FF, Baccaro MR, Moreno AM, Ferreira AJP, Jerez AJ, Pena HJF. Freqüência de agentes causadores de enterites em leitões lactentes provenientes de sistemas de produção de suínos do Estado de São Paulo. Arq Instituto Biológico, São Paulo. 2001; 68(1): 29-34. [portuguese].

[4] Brito BG, Tagliari KC, Berbel MM, Freire RL. Produção de enterotoxina termoestável, hemolisinas, colicina e fatores de colonização em amostras de escherichia colo isoladas de leitões com diarréia no sudoeste do Paraná. Scientia agrária. 2003; 4(1-2): 15-20. [portuguese].

[5] Costa MM, Sá e Silva M, Spricigo DA, Witt NM, Marchioro SB, Kolling L, Vargas APC. Caracterização epidemiológica, molecular e perfil de resistência aos microbianos de Escherichia coli isoladas de criatórios de suínos do sul do Brasil. Pesq Vet Bras. 2006; 26(1): 5-8. [portuguese]. 
[6] Quinn PJ, Markey BK, Carter ME, Donnely WJ, Leonard FG. Microbiologia veterinária e doenças infecciosas. Porto Alegre: Artmed; 2005.

[7] Associação brasileira da indústria produtiva e exportadora de carne suína (ABIPECS). Estatísticas [www]. São Paulo; [cited 2009 Oct 15]. Available from: http://www.abipecs.org.br/pt/estatisticas.html [portuguese].

[8] Soto FRM, Vuadem ER, Benites NR, Azevedo SS, Pinheiro SR, Bernardi F, Coelho CP, Vasconcellos SA. Implantação da homeopatia e avaliação dos índices de produtividade de uma granja comercial de suínos comparado com a alopatia na fase de recria e terminação. Veterinária e Zootecnia. 2007; 14(1): 7-114. [portuguese].

[9] Vuaden ER. Homeopatia na suinocultura [monography]. São Paulo: Centro de Ensino Superior de Homeopatia, Faculdade de Ciências da Saúde de São Paulo; 2005. [portuguese].

[10] Saxton J, Gregory P. Textbook of veterinary homeopathy. Oxford: Beaconsfield publishers Ltd; 2005.

[11] Ribeiro FA. Novo repertório de sintomas homeopáticos. 2th ed. São Paulo: Robe; 2000. [portuguese].

[12] Kent JT. Repertory of the homeopathic materia medica. India: B Jain publishers; 2006.

[13] Allen TF. The encyclopedia of pure materia medica. New Delhi: Jain publishers; 1982.

[14] Tyler ML. Retratos de medicamentos homeopáticos. Léo Lewkowicz, editor. São Paulo: Santos ed; 1995. v2. [portuguese].

[15] Farmacopéia homeopática brasileira. 2th ed. São Paulo: Atheneu; 1997. [portuguese].

[16] Fontes OL. Farmácia homeopática: teoria e prática. 2th ed. Barueri: Manole; 2005. [portuguese].

[17] Albrecht H, Schütte A. Homeopathy versus antibiotics in metaphylaxis of infectious diseases: a clinical study in pig fattening and its significance to consumers. Altern Therapies Health and Med. 1999; 5(5): 64-68.

[18] Berchieri JRA, Turco WCP, Paiva JB, Oliveira GH, Sterzo EV. Evaluation of isopathic treatment of Salmonella enteritidis in poultry. Homeopathy. 2006; 95(2): 94-97.

[19] Soto FRM, Vuadem ER, Coelho CP, Azevedo SS, Bonamin LV, Benites NR. Comparação entre o uso de homeopatia, alopatia e imunoprofilaxia na prevenção da Erisipela suína. Veterinária e Zootecnia. 2009; 16(1): 101-107. [portuguese].

[20] Fontes OL, Severino P, Chaud MV, Nascimento GGF, Alves MLF, Gutierrez MA. Ação terapêutica do medicamento homeopático em ratas com infecção urinária por Escherichia coli. Cultura homeopática. 2005; 4(13): 9-18. [portuguese].

[21] Silva NL, Moletta JL, Minho AP, Filippsen LF. Use of biotherapic in the controlo f natural infestation by Boophilus microplus: pilot study. Int J High Dilution Res. 2008 [cited 2009 oct 01]; 7(22): 36-38. Available from: http://www.feg.unesp.br/ ojs/index.php/ijhdr/article/view/251/337.

[22] Talamini DJD, Martins FM, Arboit C, Wolozsyn N. Custos agregados da produção integrada de suínos nas fazes de leitões e de terminação. Custos e @gronegócios. 2006 [cited 2009 nov 06]; 2: 64-83. Available from: http://www.custoseagronegocioonline.com.br/especialv2/custos\%20agregados\%20de\%20producao.pdf [portuguese]. 
[23] Talamini DJD, Martins FM, Pinheiro ACA. Rentabilidade da terminação de suínos no Estado de Santa Catarina. Concórdia: EMBRAPA suínos e aves. 2005.Technical report 404. [portuguese].

[24] Boerlin P. Antimicrobial growth promoter ban and resistance to macrolides and vancomycin in enterococci from pigs. J Clin Microbiol. 2001; 39(11): 4193-4195.

[25] Soto FRM, Vuadem ER, Benites NR, Azevedo SS, Pinheiro SR, Coelho CP, Vasconcellos SA. Avaliação dos índices zootécnicos de uma granja comercial de suínos com a utilização do tratamento homeopático. Veterinária e Zootecnia. 2008; 15(3): 577-586. [portuguese].

\section{Tratamento homeopático preventivo para Colibacillosis, na produção de suínos,}

\section{RESUMO}

Escherichia coli é o agente etiológico mais importante implicado na diarréia neonatal em suínos; a colibacilose é a enfermidade com o maior impacto na produção suína. As demandas dos consumidores por carne sem resíduos químicos e a proibição do uso de antibióticos e quimioterápicos na produção de suínos têm forçado os produtores a procurar por tratamentos curativos e preventivos alternativos. Objetivos: avaliar o tratamento homeopático como profilático na colibacilose em suínos. Métodos: o estudo foi realizado numa granja em Mato Grosso, Brasil; foram colhidas fezes de 4 leitões para pesquisar a presença de E. coli; concomitantemente foi realizado exame clínico para identificar os sintomas necessários para a escolha do medicamento homeopático. Leitões recém-nascidos foram divididos em 4 grupos (n=11-12): 1) controle: tratado com antibiótico contra a diarréia; 2) tratamento homeopático, realizado com Phosphorus $30 \mathrm{cH}$ segundo os sintomas colhidos; 3) bioterápico, realizado com Escherichia coli $30 \mathrm{cH}$ preparado da cultura da bactéria localmente isolada; 4) tratamento homeopático + bioterápico. Resultados: os 3 grupos com tratamento homeopático/isoterápico apresentaram uma redução significativa da diarréia por comparação ao grupo controle $(\mathrm{p}=0,02)$; o grupo tratado com Phosphorus 30cH + Escherichia coli $30 \mathrm{cH}$ apresentou o maior ganho de peso em relação aos outros 3 grupos $(\mathrm{p}=0,001)$. Conclusão: os tratamentos homeopático e bioterápico foram mais efetivos que o antibiótico no controle da diarréia em leitões recém-nascidos; a combinação do tratamento homeopático e isopático resultou no maior ganho de peso. Esses resultados sugerem que homeopatia e isopatia são alternativas efetivas no tratamento da diarréia por $E$. coli em suínos recém-nascidos.

Palavras-chave: Escherichia coli; Diarréia; Suínos; Homeopatia; isopatia; Efetividade

\section{Tratamiento homeopático preventivo para Colibacillosis, en la produción de porcinos}

\section{RESUMEN}

Escherichia coli é o agente etiológico más importante de la diarrea neonatal en porcinos; la colibacilosis es la enfermedad de mayor impacto en la criación porcina. La demanda de los consumidores de carne sin residuos químicos y la prohibición del uso de antibióticos y quimioterápicos en la creación de porcinos han llevado a los productores a buscar tratamientos curativos y preventivos. Objetivos: evaluar el tratamiento homeopático como profiláctico en colibacilosis en porcinos. Métodos: el estudio fue realizado en una granja en Mato Grosso, Brasil; fue recolectada materia fecal de 4 lechones investigando la presencia de E. coli; concomitantemente los animales fueron examinados clínicamente para identificar los síntomas necesarios para elegir el medicamento homeopático. Lechones neonatos fueron divididos en 4 grupos (n=11-12): 1) control: tratado con antibióticos contra la diarrea; 2) tratamiento homeopático, realizado con Phosphorus $30 \mathrm{cH}$ de acuerdo con los síntomas encontrados; 3) tratamiento bioterápico, con Escherichia coli 30cH preparado a partir de la cepa aislada; 4) tratamiento homeopático + bioterápico. Resultados: los 3 grupos con tratamiento homeopático/isopático presentaron una reducción significativa de la diarrea comparativamente al grupo 
control ( $\mathrm{p}=0,02)$; el grupo tratado con Phosphorus $30 \mathrm{cH}+$ Escherichia coli $30 \mathrm{cH}$ mostró el mayor aumento de peso con relación a los otros 3 grupos $(\mathrm{p}=0,001)$. Conclusión: los tratamientos homeopático y bioterápico fueran más efectivos que el antibiótico para controlar la diarrea en lechones recién nascidos; la asociación de tratamiento homeopático e isopático produjo el mayor aumento de peso. Estos resultados sugieren que homeopatía e isopatía son alternativas efectivas en el tratamiento de diarrea por $E$. coli en porcinos recién nacidos.

Palabras llave: Escherichia coli; Diarrea; Porcinos; Homeopatía; Isopatía; Efectividad

\section{(c)) BY-NC-ND Licensed to GIRI}

Support: authors declare that this study received no funding

Conflict of interest: Authors declare they had full access to all the data in this study and they take complete responsibility for the integrity of the data and the accuracy of the data analysis

Received: 30 Nov 2009; Revised 11 Dec 2009; Published: 17 Dec 2009.

Correspondence author: Cideli de Paula Coelho, ccideli@uol.com.br, http://www.cidelicoelho.com.br

How to cite this article: Coelho CP, Soto FRM, Vuaden ER, Melville PA, Oliveira FCS, Benites NR. Evaluation of preventive homeopathic treatment against Colibacillosis in swine production. Int J High Dilution Res [online]. 2009 [cited YYYY Month dd]; 8(29): 183-190. Available from: http://www.feg.unesp.br/ ojs/index.php/ijhdr/article/view/361/409. 